\title{
Identification of Hiochi Bacteria by Sodium Dodecyl Sulfate- Polyacrylamide Gel Electrophoretic Patterns of Whole Cell Proteins
}

\author{
Jinshichiro NaKamura, Kenji DoI, Yuko Higashida, \\ Masaaki HamaCHI and Takemitsu HoNMA \\ General Research Institute, Ozeki Sake Brewing Co., Ltd., 4-9 Imazu Dezaike-cho, \\ Nishinomiya-shi, Hyogo 663, Japan
}

Received January 21, 1991

\begin{abstract}
The whole cellular proteins of various hiochi bacteria were analyzed by sodium dodecyl sulfate-polyacrylamide gel electrophoresis (SDS-PAGE). On the basis of the electrophoretic patterns, the hiochi bacteria were generally divided into four distinguishable groups, agreeing with the conventional groupings based on physiological and biochemical characters; homo- and heterofermentative true hiochi bacilli and homo- and hetero-fermentative hiochi lactobacilli. The SDSPAGE patterns of the other lactobacilli were clearly different from that of the hiochi bacteria. The SDS-PAGE patterns of SDS-extracted protein from hiochi bacteria can be used as a simple and a useful tool for identification of the microorganisms causing putrefaction of sake.
\end{abstract}

Hiochi bacteria are alcoholphilic or alcoholtolerant lactobacilli which are able to grow in sake (Japanese traditional alcoholic beverage) containing more than $15 \%$ ethanol. Kitahara et al. ${ }^{1,2)}$ divided the hiochi bacteria into two groups according to their requirement for mevalonic acid for growth, i.e., the mevalonic acid-depending "true hiochi bacilli" and independent "hiochi lactobacilli", and further divided each of them into subgroups, homoand hetero-fermenters, according to their types of lactic acid fermentation. The homo- and hetero-fermentative true hiochi bacilli were named Lactobacillus homohiochii and Lactobacillus heterohiochii, respectively. On the other hand, the homo- and hetero-fermentative hiochi lactobacilli were found to be many species of lactobacilli such as Lactobacillus acidophilus, Lactobacillus plantarum, and Lactobacillus fermentum. Momose et al. ${ }^{3,4)}$ proposed to discriminate between the true hiochi bacilli and hiochi lactobacilli according to their $\mathrm{pH}$ range of growth, fermentation abilities of sugars, and the effects of ethanol on growth, but not based on the requirement for mevalonic acid.
The classification of microorganisms has been mainly based on morphological, physiological, and biochemical characteristics. In recent years, however, several new indices such as GC contents of cellular DNA and chemical compositions of cellular fatty acids have been introduced into bacterial systematics. For example, Vescovo et al. ${ }^{5)}$ and Weiss et al. $\left.{ }^{6}\right)$ reported that the type strains of Lactobacillus fructivorans and $L$. heterohiochii had a high degree of DNA homology with each other. Based on this observation, Kandler and Wess ${ }^{7)}$ included L. heterohiochii in L.fructivorans. The sodium dodecyl sulfate-polyacrylamide gel electrophoresis (SDS-PAGE) patterns of cellular proteins have also been studied as a mean of classifying and identifying microorganisms. $^{8,9)}$ Although identification of hiochi bacteria isolates is being done by the physiological and biochemical characteristic, ${ }^{3,4}$ such methods require special experience as well as long experimental times (10-15 days), because the growth rate of hiochi bacteria is very slow. ${ }^{10,11)}$

In this paper, the SDS-PAGE patterns of the SDS-extracted cellular proteins of hiochi 
bacteria were examined and it was found that the protein patterns could be used for a simple and reliable method for identification of hiochi bacteria.

\section{Materials and Methods}

Microorganisms. Microorganisms used in this study are listed in Table I. All hiochi bacteria marked with $\mathbf{S}$ - or $\mathrm{H}$ - were obtained from the National Research Institute of Brewing (RIB). The other hiochi bacteria were isolated

Hiochi bacteria ${ }^{b}$

Table I. LIST OF Microorganisms EXAMINED

\begin{tabular}{|c|c|c|c|c|c|}
\hline \multicolumn{3}{|c|}{ Homo-fermenters } & \multicolumn{3}{|c|}{ Hetero-fermenters } \\
\hline Group $^{a}$ & Strains & & Group $^{a}$ & Strains & \\
\hline \multirow{11}{*}{$\begin{array}{l}\text { True } \\
\text { hiochi bacilli }\end{array}$} & Lactobacillus homohiochii & $\mathrm{S}-24$ & True & Lactobacillus fructivorans & $\mathrm{H}-1$ \\
\hline & Lactobacillus homohiochii & S-26 & hiochi bacilli & Lactobacillus fructivorans & $\mathrm{H}-5$ \\
\hline & Lactobacillus homohiochii & S-27 & & Lactobacillus fructivorans & $\mathrm{H}-10$ \\
\hline & Lactobacillus homohiochii & S-35 & & Lactobacillus fructivorans & S-9 \\
\hline & Lactobacillus homohiochii & $S-40$ & & Lactobacillus fructivorans & S-19 \\
\hline & Lactobacillus homohiochii & $S-42$ & & Lactobacillus fructivorans & $\mathrm{S}-37$ \\
\hline & Lactobacillus sp. & OW-1 & & Lactobacillus sp. & $2-\mathrm{A}$ \\
\hline & Lactobacillus sp. & $2-\mathrm{C}$ & & Lactobacillus sp. & $2-S$ \\
\hline & Lactobacillus sp. & $2-\mathrm{J}$ & & Lactobacillus $\mathrm{sp}$. & TS-2 \\
\hline & Lactobacillus sp. & $3-\mathrm{C}$ & & Lactobacillus sp. & CE-9 \\
\hline & Lactobacillus sp. & $3-\mathrm{I}$ & & Lactobacillus sp. & $\mathrm{T}-4$ \\
\hline \multirow{11}{*}{$\begin{array}{l}\text { Hiochi } \\
\qquad \text { lactobacilli }\end{array}$} & Lactobacillus acidophilus & $\mathrm{H}-7$ & Hiochi & Lactobacillus fermentum & $\mathrm{H}-34$ \\
\hline & Lactobacillus sp. & S-8 & lactobacilli & Lactobacillus sp. & $S-7$ \\
\hline & Lactobacillus sp. & $\mathrm{S}-32$ & & Lactobacillus sp. & $\mathrm{H}-50$ \\
\hline & Lactobacillus sp. & $1-\mathrm{O}$ & & Lactobacillus sp. & AD-1 \\
\hline & Lactobacillus sp. & AK-1 & & Lactobacillus sp. & M-1 \\
\hline & Lactobacillus sp. & $\mathrm{T}-16$ & & Lactobacillus sp. & $2-K$ \\
\hline & Lactobacillus sp. & $15-\mathrm{G}$ & & Lactobacillus sp. & $3-E$ \\
\hline & Lactobacillus sp. & $1-P$ & & Lactobacillus sp. & $8-\mathrm{A}$ \\
\hline & Lactobacillus sp. & $1-S$ & & Lactobacillus sp. & AA-2 \\
\hline & Lactobacillus sp. & $10-\mathrm{D}$ & & Lactobacillus sp. & $1-E$ \\
\hline & Lactobacillus sp. & $74-\mathrm{O}$ & & Lactobacillus sp. & $5-\mathrm{T}$ \\
\hline
\end{tabular}

Other lactobacilli

$\begin{array}{ll}\text { Lactobacillus acidophilus } & \text { IFO } 13951^{T} \\ \text { Lactobacillus acidophilus } & \text { IFO } 13952^{c} \\ \text { Lactobacillus casei subsup. casei } & \text { IFO } 3533^{c} \\ \text { Lactobacillus casei subsup. rhamnosus } & \text { IAM } 1118^{T} \\ \text { Lactobacillus sake } & \text { IFO } 3541^{c} \\ \text { Lactobacillus plantarum } & \text { IAM } 1041^{c} \\ \text { Lactobacillus plantarum } & \text { IAM } 1216^{c} \\ \text { Lactobacillus sp. (As L. buchneri) } & \text { IFO } 3961^{c} \\ \text { Lactobacillus fermentum } & \text { IFO } 3071^{c} \\ \text { Lactobacillus fermentum } & \text { IFO } 3956^{c} \\ \text { Lactobacillus fructivorans } & \text { IFO } 13954^{T}\end{array}$

a Hiochi bacteria were grouped according to Momose's procedure. ${ }^{13}$ )

${ }^{b}$ All hiochi bacteria marked with $\mathrm{S}$ or $\mathrm{H}$ were obtained from the National Research Institute of Brewing, Japan and the other hiochi bacteria were isolated from non-sterilized sake and maintained by Ozeki General Research Institute, Japan.

c Abbreviations: IFO, Institute for Fermentation, Osaka, Japan; IAM, Institute of Applied Microbiology, The University of Tokyo, Japan; T. type strains. 
from non-sterilized sake and have been maintained by the General Research Institute, Ozeki Sake Brewing Co., Ltd. Other lactobacilli were obtained from the Institute for Fermentation, Osaka (IFO) and the Institute of Applied Microbiology, The University of Tokyo (IAM).

Culture conditions. Hiochi bacteria were cultured in SI medium $^{12)}$ containing $10 \%$ ethanol (agar-free). Ethanol was added to the sterilized medium just before inoculation. L. acidophilus IFO $1395 \mathrm{I}^{\mathrm{T}}$ and IFO 13952 were cultured in a medium containing $0.5 \%$ peptone, $0.5 \%$ yeast extract, $0.5 \%$ glucose, $0.2 \%$ lactose, $0.05 \%$ Tween 80 , and $0.1 \%$ $\mathrm{MgSO}_{4} \cdot 7 \mathrm{H}_{2} \mathrm{O}(\mathrm{pH} 7.0)$. L. fructivorans IFO $13954^{\mathrm{T}}$ was cultured in a medium containing $0.5 \%$ peptone, $0.5 \%$ yeast extract, $0.5 \%$ glucose, $0.1 \% \mathrm{MgSO}_{4} \cdot 7 \mathrm{H}_{2} \mathrm{O}$, and $0.2 \%$ fructose ( $\mathrm{pH} 5.0)$. The other lactobacilli were cultured in a medium containing $0.5 \%$ peptone, $0.5 \%$ yeast extract, $0.5 \%$ glucose, and $0.1 \% \mathrm{MgSO}_{4} \cdot 7 \mathrm{H}_{2} \mathrm{O}(\mathrm{pH} 7.0)$. Microorganisms were cultured statically until late-exponential phase at $30^{\circ} \mathrm{C}$.

Extraction of bacterial proteins. The bacteria were harvested at late-exponential phase by centrifugation and washed three times with distilled water. The cell pellet was resuspended in distilled water and cell density was set to $\mathrm{OD}^{660} 1.0(10 \mathrm{ml})$. The cell suspensions were centrifuged, the supernatants were discarded, and the residual cell pellets were mixed with $50 \mu \mathrm{l}$ of $1 \%(\mathrm{w} / \mathrm{v})$ solution of SDS and stirred with a vortex-mixer, and the cell suspension was transferred to an Eppendorf microtube. After this was left for $30 \mathrm{~min}$ at room temperature, the cell suspension was centrifuged and a portion of the supernatant was taken out into a fresh tube. This SDS-extracted solution was used for SDS-PAGE.

$S D S-P A G E$. SDS-extracted proteins were separated by SDS-PAGE by the method of Laemmli. ${ }^{13)}$ Reference molecular weight markers were obtained from Pharmacia. The concentration of polyacrylamide gel for the separation was $10 \%$. The protein solution were heated in the sample buffer $\{2.3 \%$ SDS, 5\% 2-mercaptoethanol, 20\% glycerol, $0.005 \%$ bromo-phenol-blue (w/v), $0.06 \mathrm{M}$ Tris, $\mathrm{pH} 6.8\}$ at $100^{\circ} \mathrm{C}$ for $3 \mathrm{~min}$. Ten $\mu 1$ samples were put on and developed. The gels were stained with Coomasie brilliant blue R 250 (CBB) and destained with destainig soln. $\{10 \%$ acetic acid, $25 \%$ methanol $(w / v)\}$.

Grouping of isolates of hiochi bacteria. The isolated hiochi bacteria were grouped by the procedure of Momose t $_{\text {al }}{ }^{3)}$ Briefly, all strains isolated were inoculated on to both SI medium containing $15 \%$ ethanol and glucose-bouillon medium, cultured for 10 days at $30^{\circ} \mathrm{C}$, and checked on gas formation by vasper seals. ${ }^{14)}$ Based on these results, hiochi bacteria were grouped into true hiochi bacilli, which have on alcoholphilic nature and are not able to grow in the neutral $\mathrm{pH}$ medium, and hiochi lactobacilli. These strains were further grouped into homo- and hetero-fermenters according to the type of lactic acid fermentation.

\section{Results}

\section{SDS-PAGE patterns of typical strains of hiochi bacteria}

The SDS-PAGE patterns of the SDSextracted proteins from hiochi bacteria, Lactobacillus homohiochii S-24 (true hiochi bacilli homo-fermenter), L. fructivorans (L. heterohiochii) H-1 (true hiochi bacilli heterofermenter), L. acidophilus $\mathrm{H}-7$ (hiochi lactobacilli homo-fermenter), and L. fermentum $\mathrm{H}-34$ (hiochi lactobacilli hetero-fermenter) were compared. As shown in Fig. 1, a large number of protein bands stained with CBB were observed in each lane. The patterns were quite distinctive and reproducible, and were distinguished from each other in the higher molecular weight protein regions.

\section{SDS-PAGE patterns of true hiochi bacilli}

The protein patterns of the strains of true hiochi bacteria were compared. As shown in Fig. 2, the homo-fermentative true hiochi bacteria group was characterized by a approximate $67 \mathrm{kDa}$ dark major protein band but

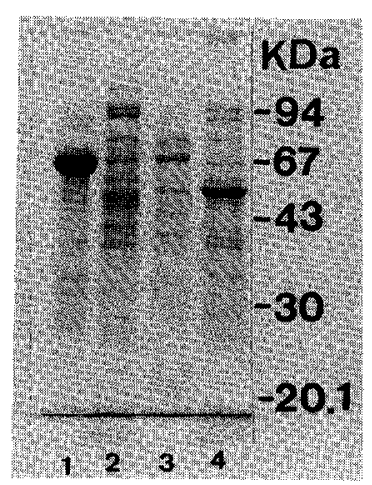

Fig. 1. SDS-PAGE Patterns of SDS-extracted Hiochi Bacterial Proteins.

Lane 1: L. homohiochii S-24, homo-fermentative true hiochibacilli.

Lane 2: L. fructivorans ( $L$. heterohiochii) $\mathrm{H}-1$, heterofermentative true hiochibacilli.

Lane 3: L. acidophilus $\mathrm{H}-7$, homo-fermentative hiochi lactobacilli.

Lane 4: L. fermentum H-34, hetero-fermentative hiochi lactobacilli. 


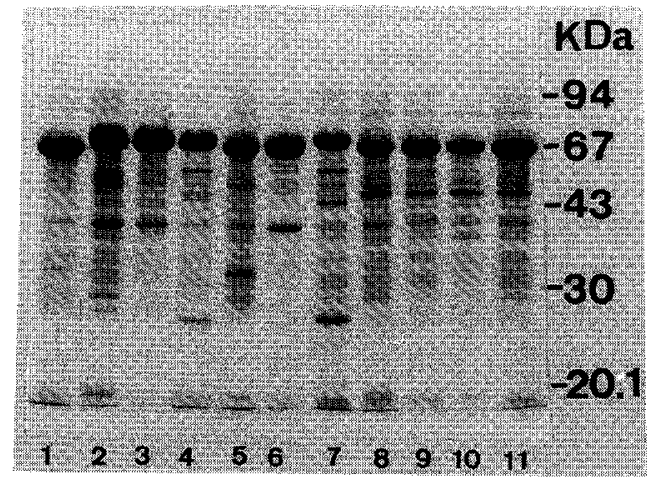

Fig. 2. SDS-PAGE Patterns of SDS-extracted Hiochi Bacterial Proteins from Homo-fermentative True Hiochi Bacilli.

Lane 1, L. homohiochii S-24; lane 2, S-26; lane 3, S-27; lane 4, S-35; lane 5, S-40; lane 6, S-42; lane 7, OW-1; lane 8, 2-C; lane 9, 2-J; lane 10, 3-C; lane 11, 3-I.

the other bands varied among strains. On the other hand, as shown in Fig. 3, all strains of the hetero-fermentative true hiochi bacilli group had great similarity in their protein patterns. Their patterns were characterized by the sharp bands of $100,95,94,79$, and $55 \mathrm{kDa}$.

\section{SDS-PAGE patterns of hiochi lactobacilli}

Both hiochi lactobacilli homo- and heterogroups did not always have completely identical patterns; they generally had two or four kinds of patterns. As shown in Fig. 4, the patterns of homo-fermentative hiochi lactobacilli were characterized by weak but sharp bands of approximate $67 \mathrm{kDa}$. These patterns were further divided into two types A (lane 1-9) and $B$ (lane 10, 11). In the type B (lane $10,11)$ a $90 \mathrm{kDa}$ protein band was detected, and in the others (type A, lane 1-9) almost the same bands were detected, which were common for strains belonging to this group. As shown in Fig. 5, the patterns of hetero-fermentative hiochi lactobacilli were characterized by dark major protein bands between 43 and $70 \mathrm{kDa}$, and two minor protein bands at 95 and $94 \mathrm{kDa}$ were detected in almost of strains belonging to this group, but the molecular masses of the major protein band were different; major protein bands were detected at 43 (lane 10, 11), 58 (lane 1, 2, 4, 5), 66 (lane 3,6, 7, 8), and 78

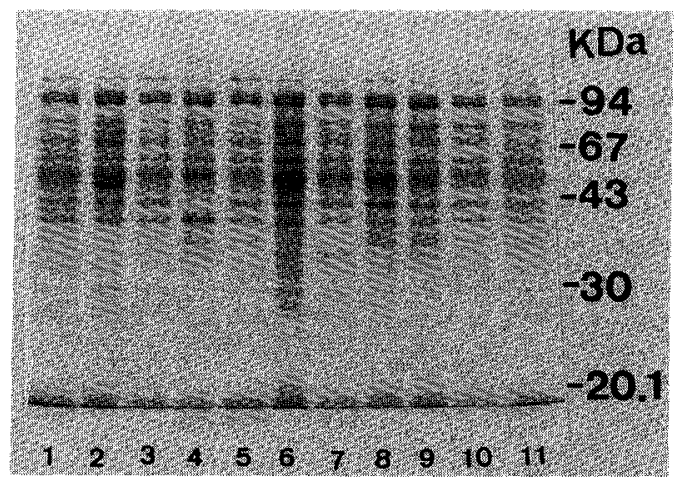

Fig. 3. SDS-PAGE Patterns of SDS-extracted Hiochi Bacterial Proteins from Hetero-fermentative True Hiochi Bacilli.

Lane 1, L. fructivorans (L. heterohiochii) $\mathrm{H}-1$; lane 2, H-5; lane 3, H-10; lane 4, S-9; lane 5, S-19; lane 6, S-37; lane 7, 2-A; lane 8, 2-S; lane 9, TS-2; lane 10, CE-9; lane 11, T-4.

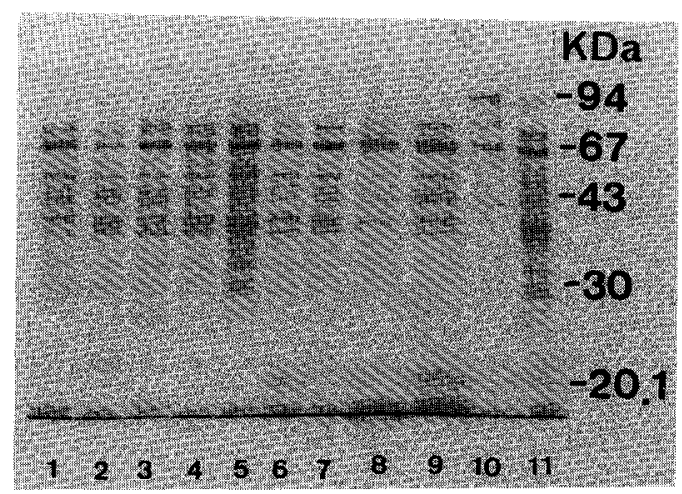

Fig. 4. SDS-PAGE Patterns of SDS-extracted Hiochi Bacterial Proteins from Homo-fermentative Hiochi Lactobacilli.

Lane 1, L. acidophilus H-7; lane 2, S-8; lane 3, S-32; lane 4, 1-O; lane 5, AK-1; lane 6, T-16; lane 7, 15-G; lane 8, 1-P; lane 9. 1-S; lane 10, 10-D; lane 11, 74-O.

(lane 9) kDa.

SDS-PAGE patterns of the other lactobacilli which were isolated from sources other than sake

The SDS-PAGE the SDS-extracted protein patterns from other lactobacilli were also compared with that of hiochi bacteria (Fig. 6). These patterns of the other lactobacterial protein bands tested were quite distinct in having their own patterns, especially, the pattern of L. acidophilus IFO $13951^{\mathrm{T}}$ (lane 


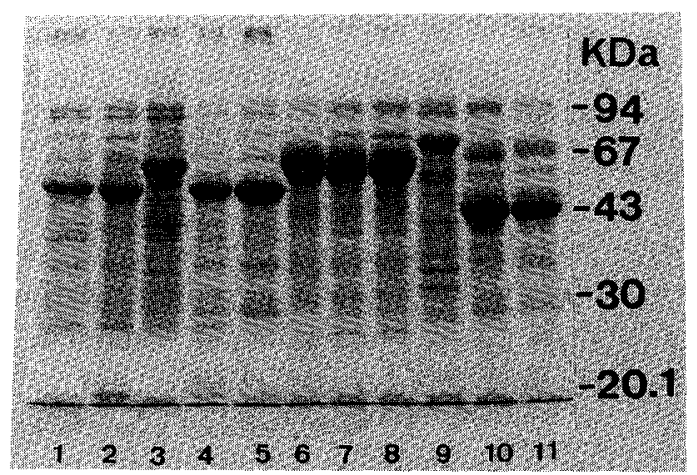

Fig. 5. SDS-PAGE Patterns of SDS-extracted Hiochi Bacterial Proteins from Hetero-fermentative Hiochi Lactobacilli.

Lane 1, L. fermentum H-34; lane 2, S-7; lane 3, H-50; lane 4, AD-1; lane 5, M-1; lane 6, 2-K; lane 7, 3-E; lane 8, 8-A; lane 9, AA-2; lane 10, I-E; lane 11, 5-T.

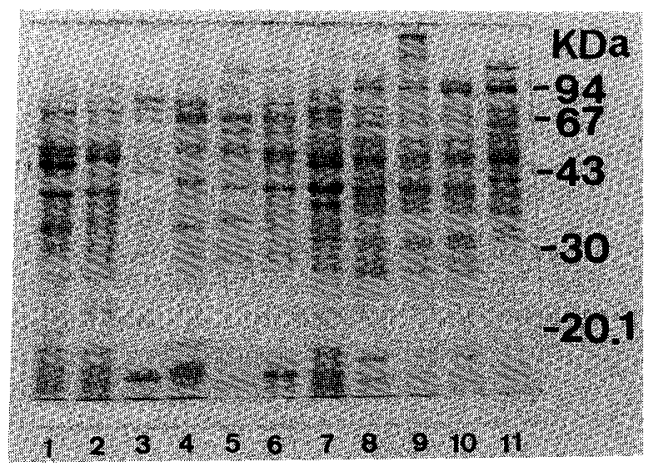

Fig. 6. SDS-PAGE Patterns of SDS-extracted Proteins of Lactobacteria.

Lane 1, L. acidophilus IFO 13951; lane 2, L. acidophilus IFO 13952; lane 3, L. casei subsp. casei IFO 3533; lane 4, L. casei subsp. rhamnosus IAM 1118; lane 5, L. plantarum IAM 1041; lane 6, L. plantarum IAM 1216; lane 7, L. sake IFO 3541; lane 8, L. sp. IFO 3961 (As L. buchneri); lane 9, L. fermentum IFO 3071; lane 10, L. fermentum IFO 3956; lane 11, L. fructivorans IFO 13954.

1) and 13952 (lane 2), L. casei subsp. casei IFO 3533 (lane 3), L. casei subsp. rhamnosus IAM $1118^{\mathrm{T}}$ (lane 4), L. plantarum IAM 1041 (lane 5), and IAM 1216 (lane 6) and L. sake IFO 3541 (lane 7) differed from the protein patterns of hiochi bacteria. However, the pattern of $L$. fructivorans IFO $13954^{\mathrm{T}}$ (lane 11) was partially similar to that of hetero-fermentative true hiochi bacilli. The two distinctive protein bands of approximate 95 and $94 \mathrm{kDa}$ were detected in almost all of the strains of hererofermentative lactobacteria tested in this study; L. fructivorans IFO $13954^{\mathrm{T}}, L$. fermentum IFO 3071, and IFO 3956, L. sp. (L. buchneri) IFO 3961 and hiochi bacteria (true hiochi bacilli and hiochi lactobacilli).

\section{Discussion}

Recently, the SDS-PAGE patterns of cellular proteins have been studied as a means of classifying and identifying microorganisms. ${ }^{8,9)}$ We found that the SDS-PAGE patterns of the SDS-extracted proteins of hiochi bacteria were generally divided into four distinctive groups, and they were in good agreement with four groupings based on the physiological and biochemical characters. Moreover their patterns were clearly different and could easily be distinguished from the patterns of other lactobacilli tested. Homo- and hetero-fermentative hiochi bacteria could be differentiated by the two distinct bands of 95 and $94 \mathrm{kDa}$ specifically found in the hetero-fermentatives. As to the homo-fermentative hiochi bacteria, the true hiochi bacteria and hiochi lactobacteria could be clearly distinguished by the differences in the amounts of the $67 \mathrm{kDa}$ major band; the higher contents were in true hiochi bacteria.

On the other hand, among hetero-fermentative hiochi bacteria, true hiochi bacteria and hiochi lactobacteria could be clearly distinguished by their electrophoretic patterns, mainly based on the major bands of 43 to $75 \mathrm{kDa}$. Uchida et al. ${ }^{15)}$ analyzed the fatty acid spectra of hiochi bacteria by gas-liquid chromatography with special reference to their classification. They reported that their spectra were divided into three groups, especially hetero-fermentative true hiochi bacilli was markedly different from other groups, but differences between homo-fermentative true hiochi bacilli and hiochi lactobacilli was undetectable. ${ }^{15)}$ On the contrary, in this study, we could clearly distinguish them by their electrophoretic protein patterns.

The group of homo-fermentative true hiochi 
bacilli was characterized by the existence of an approximately $67 \mathrm{kDa}$ major protein band but the other bands varied among strains. Momose et $a l^{3,4)}$ reported that the group was further divided into three types due to a requirement for mevalonic acid for growth. However in this group, the mevalonic acid requirements did not always agree with the results of the electrophoretic patterns. In contrast to homofermentative true hiochi bacteria, the heterofermentative true hiochi bacteria group had great similarity in their protein patterns. Momose et al. $^{4)}$ reported that this group showed a similar GC content and chemical composition of their cell walls. Uchide et al. ${ }^{15)}$ reported that the fatty acid spectra of this group showed a special pattern. Vescovo et al. ${ }^{5)}$ and Weiss et al ${ }^{6)}$ reported that the type strains of $L$. fructivorans and $L$. heterohiochii had a high degree of DNA homology. We recognized that the electrophoretic protein pattern of $L$. fructivorans IFO $13954^{\mathrm{T}}$ was partially similar to that of $L$. fructivorans $\mathrm{H}-1$. These strains have similarities in the $\mathrm{pH}$ range of growth and fermentation ability of sugars, but differ in the effects of ethanol on the growth and the requirement for mevalonic acid. The heterofermentative true hiochi bacilli group seems to be a rather homogeneous cluster.

Both groups of homo- and hetero-fermentative hiochi lactobacilli generally had two or four kinds of electrophoretic protein patterns. These groups have been reported ${ }^{1,2)}$ to be composed of many species of lactobacilli such as L. acidophilus, L. plantarum, and $L$. fermentum. It remains to be investigated whether these differences of electrophoretic protein patterns among the hiochi lactobacilli are dependent on the difference in species or not. Further experiments are needed to clarify the classification of the hiochi lactobacilli group's strains.

The hiochi bacteria are clearly discriminated from the other lactobacilli according to their ability to grow in the presence of more than
$15 \%$ ethanol. The electrophoretic protein patterns of hiochi bacteria also showed marked differences from the patterns of the other lactobacteria.

The method reported here is very simple and rapid; the identification can be done in only one day. Thus it will be useful for classification of these microorganisms, which is required for control of the sake brewing process.

Acknowledgment. The authors would like to express their thanks to Dr. Y. Nunokawa, general manager of the General Research Institute of the Ozeki Sake Brewing Co., Ltd., for his encouragement.

\section{References}

1) K. Kitahara, T. Kaneko and O. Goto, J. Gen. Microbiol., 3, 102 (1957).

2) K. Kitahara, T. Kaneko and O. Goto, J. Gen. Microbiol., 3, 111 (1957).

3) H. Momose, J. Soc. Brew. Jpn., 70, 305 (1975).

4) H. Momose, E. Yamanaka, H. Akiyama and K. Nosiro, J. Gen. Appl. Microbiol., 20, 179 (1974).

5) M. Vescovo, F. Dellaglio, V. Bottazzi and P. G. Sarra, Microbiologica, 2, 317 (1979).

6) N. Weiss, U. Schillinger and O. Kandler, System. Appl. Microbiol., 4, 507 (1983).

7) O. Kandler and N. Weiss, in "Bergey's Manual of Systematic Bacteriology," Vol. 2, ed. by P. H. A. Sneath, N. S. Mair and M. E. Sharp, Williams \& Wilkins, London, 1986, pp. 1208-1234.

8) P. J. H. Jackman, in "Methods in Microbiology," Vol. 19, ed. by R. R. Colwell and R. Grigorova, Academic Press, New York, 1987, pp. 209-225.

9) K. Kersters and J. De Ley, in "Microbiological Classification and Identification," No. 8, ed. by M. Goodfellow and R. G. Board, Academic Press, New York, 1980, pp. 227-297.

10) H. Momose, S. Miyake and K. Nosiro, J. Soc. Brew. Jpn., 65, 999 (1970).

11) H. Momose and K. Nosiro, J. Soc. Brew. Jpn., 65, 1108 (1970).

12) S. Sugama and T. Inokuchi, J. Soc. Brew. Jpn., 65, $720(1970)$.

13) U. K. Laemmli, Nature, 227, 680 (1970).

14) K. Nosiro and H. Momose, J. Soc. Brew. Jpn., 65, 726 (1970).

15) K. Uchida and K. Mogi, J. Gen. Appl. Microbiol., 19, 233 (1973). 